Journal of English Language Teaching and Literature (JELTL)

\title{
DELIVERING MESSAGES THROUGH COMIC STRIP AS LEARNING MEDIA: An Analysis of Message Forms
}

Fitria Iswari

fitriaiswari@gmail.com

Desain Komunikasi Visual, Bahasa dan Seni, Universitas Indraprasta PGRI

\begin{abstract}
Communication is an activity that cannot be stopped in human life. Especially during the Covid 19 pandemic, face-to-face communication is difficult. This is also quite influential in the world of education where during the Covid-19 pandemic there were many face-to-face meetings between lecturers and students through virtual face to face. In the learning process, sometimes students are embarrassed or reluctant to express their opinions. In this study, researchers tried to use comic strip learning media as a medium for conveying opinions from students. This study used qualitative method with data collection obtained from the analysis of the form of messages from comic strip was made by students. The purpose of this study is to determine the types of messages made by students through comic strip media with educational themes. From the data, it shows that 21 comic strips have informative messages, namely 52.5\%, and 19 comic strips that have persuasive form messages or $47.5 \%$ of the percentage. While the coercive message form shows the number 0 . From this study it can be concluded that comic strips can be an alternative learning medium in the process of delivering messages or opinions.
\end{abstract}

Key words: Learning Media, Comic strip, Message form Analysis

\section{INTRODUCTION}

Communication is an important part in human life. Almost every day humans do communication both verbally and nonverbally, give information to each other, or persuade someone to do something. During the Covid-19 pandemic, all activities have almost changed, included in the learning and learning process. Definitely in the new policies and habits the lecturer faces some obstacles, for example in the virtual learning and teaching process. During the class $\mathrm{He}$ met the internet network problem or the passive class, because students also sometimes have same problem. In this situation, lecturers often found the class with less students who participated in class, for example, when the lecturer gave students the opportunity to give their opinions to the material, students tended to be embarrassed and did not answer, and only a few students actively participated in the virtual class. 
Journal of English Language Teaching and Literature (JELTL)

P-ISSN 2623-0062

Volume 4 No. 1, February 2021

E-ISSN 2622-9056

Universitas Banten Jaya

Education is one of human needs, starting from early childhood to higher education, which is an important part in human life. Almost 10 months start from March 2020 the Learning Process must be done virtually. The government's decision to carry out learning activities virtually raises pros and cons in the public. Based on the news in https://www.timesindonesia.co.id/ which was title "UNICEF and the Indonesian Parliament discussed the Pros and Cons of Virtual Learning" in the Match Webinar, TIMES. The cons, especially in the $3 \mathrm{~T}$ area (outermost, underdeveloped, and foremost) they faced availability of gadget and internet network access. Moreover, students who often felt bored and sleepy during the online learning process. The news from https://www.timesindonesia.co.id (2020) Deputy Chairman of Commission X DPR RI Hetifa Sjaifudian said that the findings of the Ministry of Education and Culture through Balitbang survey is some students studied less than 3 hours per day so that it has the potential to reduce children's rights to get the good education, especially in the $3 \mathrm{~T}$ area ". Students in $7^{\text {th }}$ semester learnt about the history of education and PGRI. The material discuss about the education and some issues that related to education policy in Indonesia, such as 
Journal of English Language Teaching and Literature (JELTL)

P-ISSN 2623-0062

Volume 4 No. 1, February 2021

E-ISSN 2622-9056

Universitas Banten Jaya

long time. It means learning media affect the teaching learning process.

Comic means pictures, and symbols are side by side in a certain order, to convey information or achieve aesthetic responses from the reader(Mc Cloud.S).Comic strip is not only to entertain reader but also can be leraning media or public service media . They NG.William et al.,(2016) design comic is to give awareness to social media users, about the importance of using social media responsibly and wisely, according to rules made in the Information and Electronic Transaction Act (UU ITE). In here the rreseracher design the media to give information. More over Ramadhani \& Putra (2017) do the research in titled Comic strip as social critical media, and the result Show that creators use comics as media of delivery of messages in the form of social criticism, by doing various considerations before using, moreover, the comics themselves are used by creators to perform social movements such as the \#MasihMelawanAsap and \#BerbagiHarapan movements. See from some research that comic strip can deliver the message either to criticize or to inform, therefore the writer chose comic strip as an alternative media to see the form of the message, whether it was 
Journal of English Language Teaching and Literature (JELTL)

P-ISSN 2623-0062

Volume 4 No. 1, February 2021

E-ISSN 2622-9056

Universitas Banten Jaya

At this stage the writer prepared literature

related to this research. Then prepared the material that would be given to students.

\section{Data Collection}

At this stage the object research was the work of 7 th semester DKV study program students who made comic strips with educational themes. The writer as a lecturer asks students to make comic strips containing positive things related to education.

\section{Data Processing.}

At this stage, after obtaining the data, the next action was to analyze the results of the writing with analysis theory. In this research the writer wanted to analyze the form of messages in comic strips, therefore the writer used the theory of message forms in communication. According to A.W. Widjaja and M. Arisyk Wahab( 2000) who divided the form of messages into three, namely: Informative, Persuasive, and Coercive. After the students made a comic strip with the theme of education. Then the data was obtained and analyzed, the final stage was to take conclusions on the contents of the comic strip message.

\section{DISCUSSION}

Topic analysis

\begin{tabular}{|l|l|}
\hline No & Name of topic
\end{tabular}

\section{a. Analysis of the themes and topics of the comic strip}

Themes are the basis for the content of a story. As stated by Nurgiantoro, a theme is a general basic idea (meaning) that supports a literary work as a semantic and abstract structure that is repeatedly raised through motives and is usually carried out implicitly. (Nurgiyantoro, 2013: 115). In other words, a theme is the core of an idea / thought that becomes the basis or reference for a story, which is intended to limit the story's content so that it does not extend far from the theme. In this study students were asked to make a comic strip with educational theme that was able to provide information or positive values to the reader. from.

From a theme then followed by a topic. Topic is a subject that is described or told in a story. According to the Big Indonesian Dictionary, the. Discussion The selection of topics that were related to educational themes which was presented in the following table:

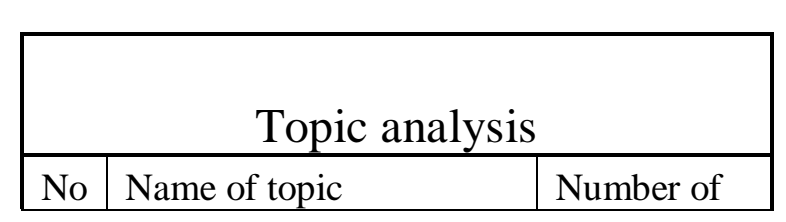


Journal of English Language Teaching and Literature (JELTL)

P-ISSN 2623-0062

Volume 4 No. 1, February 2021

E-ISSN 2622-9056

Universitas Banten Jaya

\begin{tabular}{|r|l|r|} 
& & Students \\
\hline 1 & Wasting the time & 5 \\
\hline 2 & High passion in study & 5 \\
\hline 3 & Free of internet quota & 3 \\
\hline 4 & Zoning system & 4 \\
\hline 5 & Virtual learning process & 7 \\
\hline & PPDB ( New students & 1 \\
\hline 6 & Admission) & 1 \\
\hline 7 & The benefit of gadget & 1 \\
\hline 8 & BOS Fund & 3 \\
\hline & KIP (Kartu Indonsia & \\
9 & Pintar)/ & 2 \\
\hline 10 & KJP(Kartu Jakarta Pintar & 2 \\
\hline 11 & Discipline & 3 \\
\hline 12 & UKT Scholarship & 1 \\
\hline 13 & K13 Curriculum & 2 \\
\hline 14 & bullying & 40 \\
\hline & &
\end{tabular}

Meanwhile, from the table, there are several topics that are rarely discussed by students, namely; BOS, advantage of gadget, and K13 Curriculum

From the discussion, it can be concluded that the topic that is many discussed is the online/ virtual learning system. In the story was told that students found the difficulty in online learning system, but in the process students felt helped by the teacher's explanation, so students are required to be more independent than before.

\section{b. Comic strip learning media.}

Table 1.Analysis of Comic Strip Topic

From the 40 students who created there were 14 different topics. The topic was most chosen by students was the topic of online learning systems, this was widely chosen because during the Covid-19 pandemic, which began in March 2020, all students in Indonesia were encouraged to carry out virtual learning activities, and they knew well the process of online learning. Furthermore, the topic that is many to discuss is the attitude of students in studying, namely enthusiastic about learning and wasting time. The topic is able to give positive moral messages for the readers.

From previous research, comic strips have a positive impact as a learning media in the learning and learning process. Research by Iswari(2020) with the title "Use of comic strips in Future Tense: Classroom Action for Visual Communication Students" showed an increase in learning outcomes by $18 \%$. In addition a research conducted by Sasti Karmiani (2018) in an article entitled The Use of English Comic Media as an Effort to Improve Reading Comprehension Ability in Class VIII of SMPN 3 Teluk Kuantan. From the results of this study, the students' reading comprehension ability increased to $75.23(80.95 \%)$ and was 
Journal of English Language Teaching and Literature (JELTL)

P-ISSN 2623-0062

Volume 4 No. 1, February 2021

E-ISSN 2622-9056

Universitas Banten Jaya

included in the good criteria. This shows

that the comic strip can be accepted as a learning media.

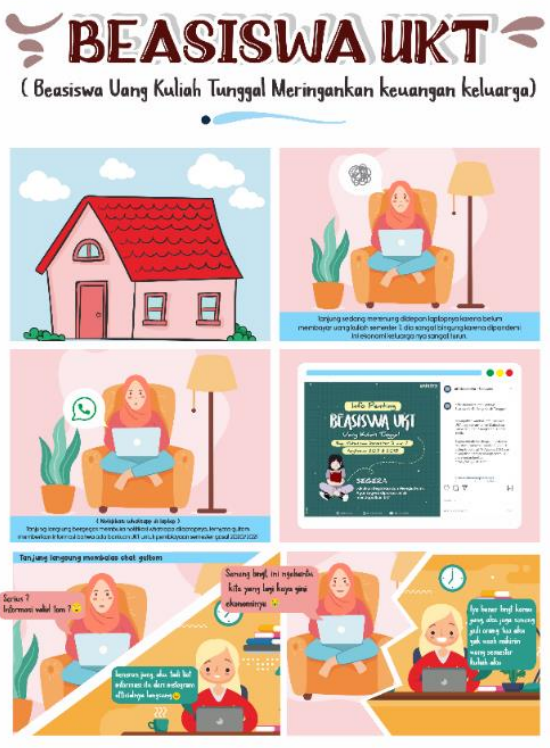

Picture 1. Comic strip

Sources :private document

Based on the picture, the comic strip is made digitally. With a minimum of 8 panels and equipped with word balloons, which contain their opinions / opinions about education. not all of students made comics digitally, there are some students who made manual methods or drew manually to complete the comic.

The result from observations and interviews with students. Students are more comfortable to convey their opinion into a comic strip than speaking directly. Most students are happy with things that are visual in nature, therefore students feel more comfortable when expressing opinions using comic strips compared to writing in the form of sentences or paragraphs because most of them love drawing.

\section{c. Analysis of the message form}

Humans cannot avoid the communication. Communication bridge the interests and needs of each individual. Messages are part of communication. One of the communication requirements besides the communicator (the message giver) and the communicant (the message recipient) is the message itself. Message is a product or the outcomes of communication activities. Conveying information / messages can be verbal or nonverbal. To get effective message, the sender must be able to go through of interpreting of receiver. The good messages consist of words and symbols to the recipient (Kotler \& Amstrong, 2010, p. 123). Symbol that are understood by both communicator and communicant. Meanwhile, according to A.W. Wijaya (2000: 15) communication is the delivery of information and 
Journal of English Language Teaching and Literature (JELTL)

P-ISSN 2623-0062

Volume 4 No. 1, February 2021

E-ISSN 2622-9056

Universitas Banten Jaya

understanding from one person to another. It can be concluded that communication is providing information to other people.

Discourse analysis is a study of the structure / structure of messages in communication. In discourse analysis, there are three points of view on language, namely:

1. Language as a bridge between humans and outside object of themselves. Discourse analysis is to describe language, and sentence rules. Discourse measurement based on truth / untruth (Eriyanto, 2006: 4).

2. The second view, the subject as a central / main factor in discourse activities and social relationships. (Eriyanto, 2006: 5).

3. The third view, language is understood as a representation that has a role in forming certain subjects, certain discourse themes, and strategies in it. (Eriyanto, 2006: 6).

As we know, the form informative messages presents facts and data to the audience. Then reader then determines / concludes the information. Here are some comic strips that have been made and have informative messages. Some comic strips

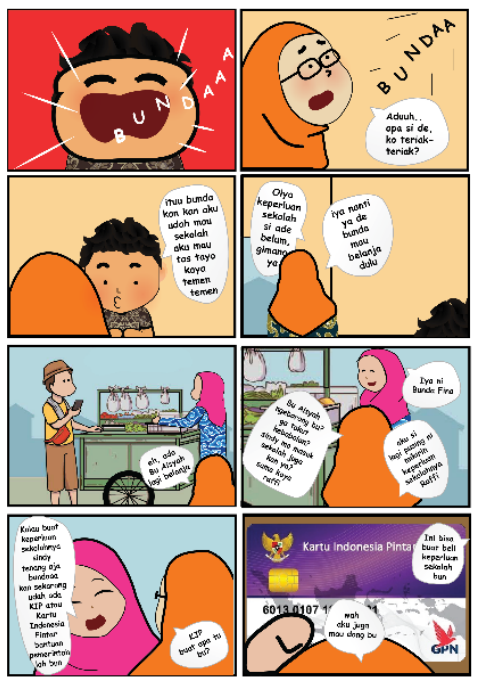

Picture 2. KIP topic

Source: Private document

In picture no 2 , there is a comic strip with 8 panels, where the dominant characters are two housewives, a child and a vegetable seller. It is said that there was a mother who is shopping for need at a vegetable seller. From inside of the house, a child screams because of he asks for school needs from his mother, but the mother has not been able to buy it. When leaving the house, accidentally a womn who is her 
Journal of English Language Teaching and Literature (JELTL)

Volume 4 No. 1, February 2021

E-ISSN 2622-9056

Universitas Banten Jaya

neighbor is shopping and overhears the conversation between the her and his child. Then the woman informs about the KIP (Smart Indonesia Card) which is one of the government programs to help students fulfill their needs. In the sentence "don't be worry of your child school needs mom, now there is a KIP with government assistance," the sentence has an informative message giving information about KIP.
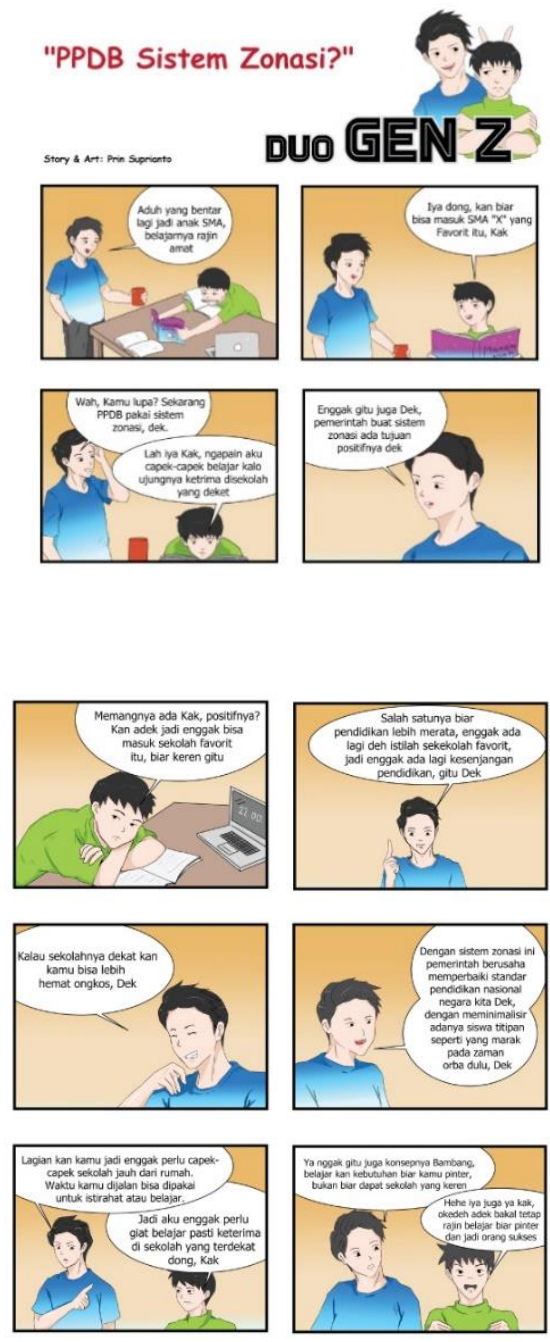

Picture 3. Zoning system Source :Private Document

In picture 3 there are 2 pages of a comic strip consisting of 10 panels and has the title "PPDB Zoning System" on the top left. The characters in the comic strip are 2 siblings Aldo, the younger brother, are actively studying so that their school exam scores get good results. Aldo always studies hard so he can enroll the favorite high school he dreams of. Anto, his older brother, came to give him a drink so his younger brother would be more enthusiastic about studying. In the middle of the chat, Anto reminded that the admission of new PPDB students was now using a zoning system. He explained that the zoning system made by the government has positive goals including equal distribution of education, it also has an economic impact where with this zoning system students are more effective because of the close distance to schools, so it can cut costs for students to go to school. In addition, this zoning system also aims to minimize corruption in the form of "entrusted students" so that the quality of education in Indonesia is getting better. In the story, there is a form of informative messages that are packaged in simple conversation and have a positive message so learning must be accompanied by persistent and study hard. The sentence that shows the 
Journal of English Language Teaching and Literature (JELTL)

P-ISSN 2623-0062

Volume 4 No. 1, February 2021

E-ISSN 2622-9056

Universitas Banten Jaya

meaning of informative is "one of them so

that education is evenly distributed, there is

no longer the term favorite school, so there

are no more educational gaps, that's how it

is" Behind the controversy over the rejection

or protest of the PPDB (New Student

Admissions) system with the zoning system,

the author provides information on the advantages of the zoning system. In other words, the author wants to provide information about the PPDB zoning system.

\section{C.2 The Forms of Persuasive Messages}

In messages that are persuasive, the content of the message is in the form of an invitation or appeal which is expected to be able to give the audience a change of attitude.
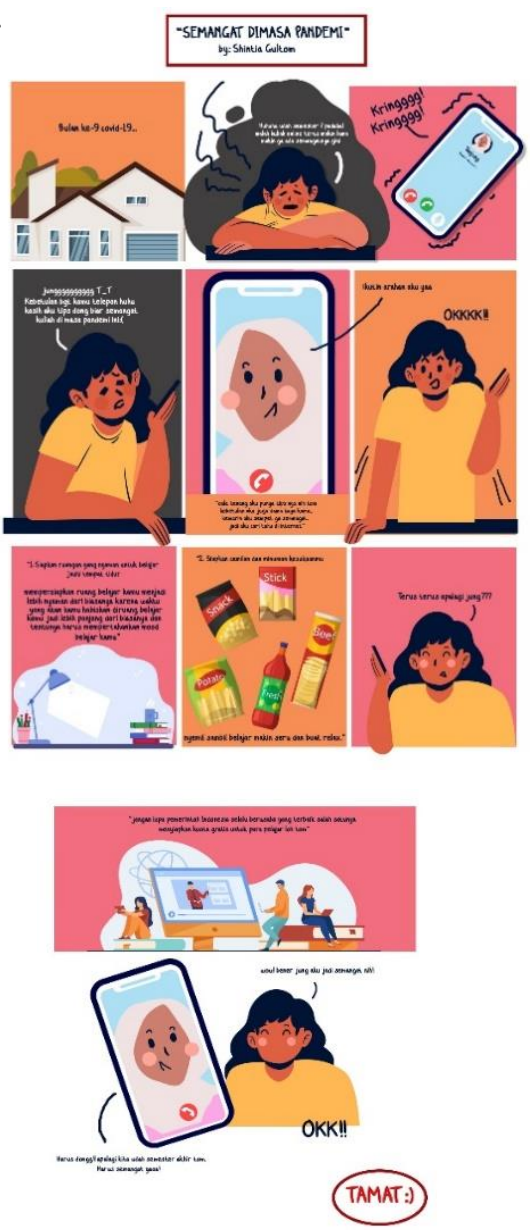

picture 4. Virtual/ online Learning

Source : Private Document

The comic strip entitled "The Spirit of the Pandemic" consists of 11 panels consisting of 2 pages. In the comic strip, there are 2 characters. Gultom is a student who feels bored in studying online and begins to lose his enthusiasm for learning. Then his close friend calls and give advice or tips to always be enthusiastic in the learning process virtually, and finally his friend got energy and became enthusiastic . A series of tips for eliminating boredom in the virtual learning process is an information that aims to influence readers, and in the end readers make a change of attitude and follow these tips. On the second page there is the word "you have to, especially we are in the last semester now, Tom, we have to be excited!" the word "we have to be excited" is form of a persuasive message because it contains an invitation element.

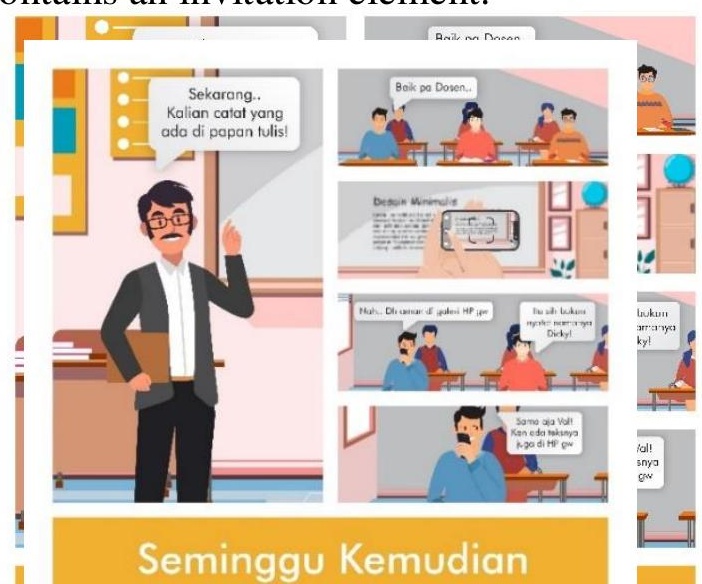


Journal of English Language Teaching and Literature (JELTL)

P-ISSN 2623-0062

Volume 4 No. 1, February 2021

Universitas Banten Jaya

\section{Picture 5: lazy}

\section{Source :private document}

The comic strip discusses the topic of "Lazy", in which the comic strip consists of 10 panels. The story has several characters, 2 male students as the main character, and a lecturer. Starting in the learning and teaching process where the lecturer asks students to take a note the material that has been given. Other students took notes in their notebooks, but Dicky only took pictures of the material on the blackboard using his cellphone camera. Nauval had reminded him to take notes, not take pictures, but Dicky insists loudly and said "it's safe in my cellphone gallery". A week later the lecturer gives a test so that the students could open their notebooks. But unfortunately Dicky forgot to copy the pictures containing the material into a notebook. Because of what he had done he was very sorry and said "yeah next time I
E-ISSN 2622-9056

don't do it again". From this sentence, it can be concluded that the character feels sorry for his false. And he promised do not do it more. This story gives moral values, and suggest to audience not to follow what he is doing. In the form of a message that is persuasive, the writer expects positive changes, it is hoped that the audience will be enthusiastic and diligent in studying.

There is no coercive form of message at all comic strip, here is a diagram of the form of the message:

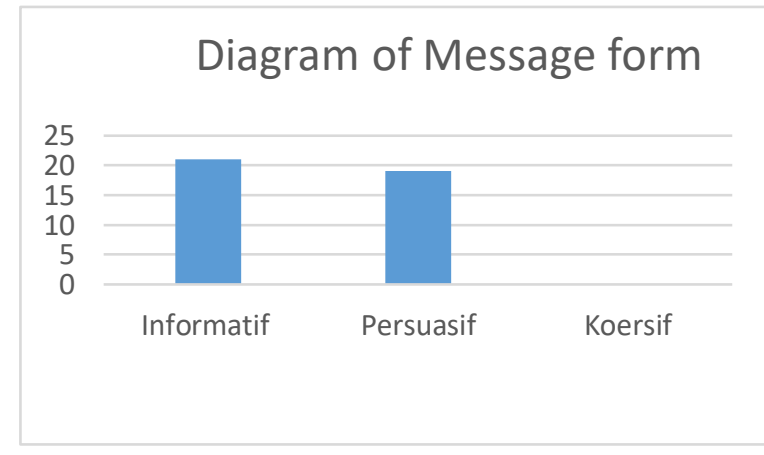

Picture 6: Diagram of messages form analysis Source : private document

The diagram shows that the message form contained in the comic strip is dominated by informative messages of 21 out of 40 students, which contain information on the theme of education, including: school operational assistance (BOS), KIP (card Indonesia Pintar), KJP (Smart Jakarta Card), Giving UKT Scholarships, Quota internet free, PPDB 
Journal of English Language Teaching and Literature (JELTL)

P-ISSN 2623-0062

Volume 4 No. 1, February 2021

E-ISSN 2622-9056

Universitas Banten Jaya

zoning system, K-13, and Online/ virtual

Learning.

Besides informative messages, there are also persuasive forms of messages that expect positive changes for the audience. From the data contained in the diagram, 19 students made comic strips in a persuasive form, among others, the topics taken were: enthusiasm for learning, wasting time, bullying, laziness, and discipline. In the form of a persuasive message, the writer hopes that the audience's behavior will change. For example, coming to school on time, doing a good job, don't procrastinate, and have high passion.

\section{CONCLUSSION}

Communication is an activity that cannot be stopped in the form of verbal and non-verbal communication. From the analysis of the data obtained, it can be concluded that the comic strip learning media is able to become an alternative media for students in conveying a message with the description. The results of the analysis of the message form on comic strips show that many students make comic strips in the form of informative messages about education. Counted $52.5 \%$ of students conveyed informative messages. Then, The topic of most interest in giving opinions was

online/ virtual learning, there were 7 students. The last Comic strip learning media can be a good communication tool/media during the learning process.

It is important for other researcher to do further research to complete this research. Researcher not only analyze the comic strip but also create it as a leaning media in digital. In pandemic era a digital learning medium is very helpful. Comic not only entertain the readers but also educate them. Comic which is designed Thus teaching learning is more fun

\section{REFERENCES}

Djamarah, S.B \& Zain,A (2006). Strategi Belajar Mengajar. Jakarta: Rineka Cipta.

Eriyanto,(2006)Analisis Wacana Pengantar Analisis Teks Media, Yogyakarta:Lkis.

Fitria, Dian, Fenti(2020). PENGGUNAAN COMIC STRIP PADA MATERI FUTURE TENSE: TINDAKAN KELAS PADA MAHASISWA DKV UNIVERSITAS INDRAPRASTA PGRI. El-Bannar Jurnal Pendidikan dan Pengajaran.3(1) 27-34.

Karmiani, S. (2018). Penggunaan Media Komik Berbahasa Inggris Sebagai Upaya Meningkatkan Kemampuan Membaca Pemahaman Bahasa Inggris Pada Kelas VIII SMPN 3 Teluk Kuantan. Jurnal PAJAR (Pendidikan dan Pengajaran) Program Studi 
Journal of English Language Teaching and Literature (JELTL)

P-ISSN 2623-0062

Volume 4 No. 1, February 2021

E-ISSN 2622-9056

Universitas Banten Jaya

Pendidikan Guru Sekolah Dasar

FKIP Universitas Riau, 2(6):883-890

Kotler, P. \& Amstrong, G. (2008). Prinsipprinsip pemasaran. Jilid 2 (12th ed.). (Bob Sabran, Trans.). Jakarta: Penerbit Erlangga.

Mc Cloud.S. 2001. Understanding Comics. Kepustakaan Populer Gramedia.

Nurgiyantoro, Burhan. 2013. Penilaian Pembelajaran Bahasa Berbasis Kompetensi. Yogyakarta: Badan Percetakan Fakultas Ekonomi Universitas Negeri Yogyakarta.

Ng. William, S., Agung, A., \& Jacky, C. (2016). Perancangan Komik Strip Sebagai Media Layanan Masyarakat Untuk Bijak Dalam Bersosial Media. Jurnal DKV Adiwarna, 1(8), 11. http://publication.petra.ac.id/index.php/ dkv/article/view/4461/4088

Sugiyono. (2005). Memahami PenelitiAN Kualitatif. Bandung: Afabeta

UNICEF dan DPR RI Kupas Pro Kontra Pembelajaran Daring di Webinar Match! TIMES

(https://www.timesindonesia.co.id/), diakses 10 Desember 2020

Widjaja, A.W,(2000)Pengantar Studi Ilmu Komunikasi, Jakarta:Rineka Cipta. 